\title{
Spontaneous achlorhydria with atrophic gastritis in the Zollinger-Ellison syndrome
}

\author{
H. G. DESAI AND F. P. ANTIA \\ From the Pui Department of Gastroenterology, BYL Nair Charitable Hospital, Bombay
}

SUMMARY This case report describes the occurrence of spontaneous, persistent achlorhydria in a patient with markedly raised basal acid secretion and diarrhoea for over two years (ZollingerEllison syndrome). Achlorhydria was due to the rapid development of severe atrophic gastritis in a gastric mucosa that had previously shown markedly increased numbers of parietal cells.

Non-beta cell tumours of the islet of Langerhans are known to cause two syndromes: first the ZollingerEllison syndrome characterized by markedly increased basal gastric acid secretion, recurrent peptic ulceration, and/or chronic diarrhoea (Zollinger and Ellison, 1955; Zollinger and Grant, 1964). The manifestations of this syndrome are due to the constant secretion of a hormone, gastrin, by primary and metastatic tumour cells (Gregory, Tracy, French, and Sircus, 1960; Hallenbeck, Code, and Kennedy, 1963; Gregory, Grossman, Tracy, and Bentley, 1967). About 260 cases of the Zollinger-Ellison syndrome were reported up to 1964 (Ellison and Wilson, 1964). The second syndrome is 'pancreatic cholera', characterized by watery diarrhoea, profound hypokalaemia, and hypo- or achlorhydria (Brown, Neville, and Hazard, 1950; Verner and Morrison, 1958; Chears, Thompson, Huteheson, and Patterson, 1960; Murray, Paton, and Pope, 1961; Telling and Smiddy, 1961; Espiner and Beaven, 1962; Brown and Crile, 1964; Matsumoto, Peter, Schultze, Hakim, and Franck, 1966). The manifestations of this syndrome probably result from secretion of an unknown hormone (gastrin excluded) interfering with the fluid and electrolyte transfer in the small bowel (Hindle, McBrien, and Creamer, 1964). Sixteen such cases have been reported up to 1966 (Matsumoto et al, 1966).

This report is of a patient with markedly raised basal acid secretion (without peptic ulceration), watery diarrhoea, steatorrhoea, and loss of weight observed over a period of two years followed by spontaneous, persistent achlorhydria, remission of diarrhoea, and gain in weight. To our knowledge, spontaneous achlorhydria with severe atrophic gastritis in a patient with the Zollinger-Ellison syndrome has not previously been reported.

\section{CASE REPORT}

The patient, a man aged 53 years, was first seen in June 1966 with symptoms of frequency of stool (4 to 5/day) without blood and mucus for about one and a half years. His weight had fallen from 48 to $34 \mathrm{~kg}$ during the same period. The stools were watery, moderate in quantity, and not offensive. The patient denied any recent or past history of pain in the abdomen or back, heartburn, vomiting, or haematemesis. Gastric function tests showed a high basal acid secretion consistent with the diagnosis of Zollinger-Ellison syndrome (Table I). On large doses of oral antacid and anticholinergic drugs throughout the waking hours, neither the diarrhoea nor the weight improved significantly though parenteral anticholinergic treatment effectively reduced acid output (Table II). Laparotomy was performed in June 1967 with a view to detect and remove any localized pancreatic tumour. A thorough exploration failed to reveal any tumour in the pancreas or duodenum (not opened) or any enlargement of abdominal lymph nodes. The abdomen was closed (as planned) without performing total gastrectomy or blind distal pancreatectomy. High basal acid secretions were again observed in July 1967, and in April and May 1968. From January 1968 he passed one or two semisolid stools a day and his weight was $44 \mathrm{~kg}$ in April 1968. Since May 1968 , he has passed one solid stool a day and his weight is increasing (46 kg, November 1968; $48 \mathrm{~kg}$, January 1969). Achlorhydria after adequate histamine stimulation was noted for the first time in November 1968 and subsequently in January 1969 (Table I). The patient is now asymptomatic.

FAMILY HISTORY The patient's father died of accidental injury at the age of 35 years and the mother at the age of 55 years (the cause is not known). His sister died at the age of 45 years of pulmonary tuberculosis, one brother died at the age of 65 years (cause unknown), and the other (62 years) is living and healthy.

INVESTIGATIONS On examination, the findings were: 
TABLE I

RESULTS OF GASTRIC FUNCTION TESTS IN A PATIENT WITH ZOLLINGER-ELLISON SYNDROME FOR THREE YEARS Date

\begin{tabular}{llll} 
Secretion & \\
\hline Basal & \multicolumn{1}{l}{ Stimulated } \\
\hline $\begin{array}{l}\text { Volume } \\
(\mathrm{ml} / \mathrm{hr})\end{array}$ & $\begin{array}{l}\text { Acid Output } \\
\text { (m-equiv/hr) }\end{array}$ & $\begin{array}{l}\text { Volume } \\
(\mathrm{ml} / \mathrm{hr})\end{array}$ & $\begin{array}{l}\text { Acid Output } \\
\text { (m-equiv/hr) }\end{array}$
\end{tabular}

\begin{tabular}{ll} 
Basal: Stimulated \\
\hline Concentration $\quad$ Acid \\
& Output
\end{tabular}
Method

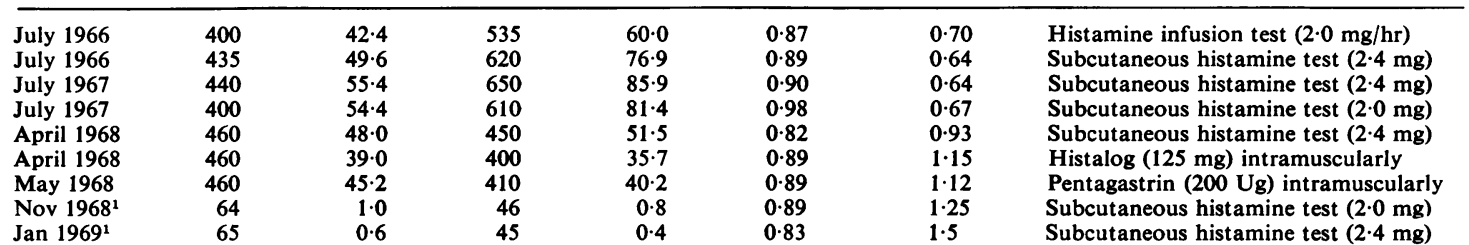

${ }^{1} p \mathrm{H}=5 \cdot 5$ (basal and stimulated)

TABLE II

THE EFFECT OF PARENTERAL ATROPINE ON BASAL ACID SECRETION IN THE ZOLLINGER-ELLISON SYNDROME

\begin{tabular}{llll} 
Time $($ min $)$ & $\begin{array}{l}\text { Volume/15 } \\
\min (\mathrm{ml})\end{array}$ & $\begin{array}{l}\text { Concentration } \\
(\text { m-equiv } /)\end{array}$ & $\begin{array}{l}\text { Acid Output } \\
(\text { m-equiv/15 min) }\end{array}$ \\
\hline Basal & 120 & 100 & $12 \cdot 0$ \\
$1-15^{1}$ & 110 & 108 & $11 \cdot 88$ \\
$16-30$ & 65 & 100 & $6 \cdot 5$ \\
$31-45$ & 43 & 112 & $5 \cdot 82$ \\
$46-60$ & 38 & 96 & $3 \cdot 65$ \\
$61-75$ & 46 & 116 & $5 \cdot 34$ \\
$76-90$ & 65 & 100 & $6 \cdot 5$ \\
$91-105$ & 50 & 100 & $5 \cdot 0$ \\
$106-120$ & 62 & 98 & 6.08
\end{tabular}

${ }^{1}$ Injection atropine $1 / 100 \mathrm{gr}$ intramuscularly.

weight $34 \mathrm{~kg}$, generalized wasting of muscles, nails pink, no clubbing; pulse $78 / \mathrm{min}$; blood pressure $110 / 70 \mathrm{~mm}$ of $\mathrm{Hg}$; no oedema of feet, no jaundice, no enlargement of thyroid or lymph nodes. Examination of different systems was negative. Investigations showed haemoglobin $14.0 \mathrm{~g} / 100 \mathrm{ml}$; peripheral smear normal; total and differential white blood count normal; erythrocyte sedimentation rate $10 \mathrm{~mm} / \mathrm{hr}$; bone marrow normoblastic. A urine and stool examination was normal. A chest radiograph was normal. SGOT was 12 units, SGPT 6 units; total proteins $3.45 \mathrm{~g} / 100 \mathrm{ml}$ (albumin $2.2 \mathrm{~g} / 100 \mathrm{ml}$, globulins $1 \cdot 25 \mathrm{~g} / 100 \mathrm{ml}$ and $\mathrm{L} 1=0 \cdot 12, \mathrm{~L} 2=0 \cdot 29, \mathrm{~B}=$ $0.36, r=0.48)$; thymol turbidity 0.3 units, serum alkaline phosphatase 6.1 (1967) and 6.0 (1969) Bodansky units; serum calcium 11.6, 12.0 (1967), and 10.4 (1969) $\mathrm{mg} / 100$ $\mathrm{ml}$; serum phosphorus $2 \cdot 2,1 \cdot 3$ (1967), and 4.7 (1969) $\mathrm{mg} / 100 \mathrm{ml}$; serum sodium $141.0 \mathrm{~m}$-equiv/1; serum potassium 4.9 m-equiv/l; serum chloride $96.8 \mathrm{~m}$-equiv/l. A skull radiograph was normal; radiographs of the spine and limbs showed generalized mild osteomalacia. An electrocardiogram was normal. Fasting blood sugar was 105 $\mathrm{mg} / 100 \mathrm{ml}$; D-xylose excretion $4.0 \mathrm{~g} /$ day $(5 \mathrm{~g}$ dose). The average daily faecal fat excretion was $16 \cdot 6-45.8 \mathrm{~g}$ (August 1966) and 10.0 g (February 1969); ${ }^{58} \mathrm{Co}-$ vitamin $B_{12}$ absorption $41 \%$ on faecal excretion (1966), $15 \%$ on Schilling's test (1969). A jejunal biopsy showed leaves (dissecting microscope) and normal villous height (light microscope). Culture of small intestinal fluid showed no organisms and the $p \mathrm{H}$ of the content of the first loop of jejunum was 1. A gastric biopsy (Fig. 1, 1966) showed markedly increased glandular structure with an increased number of parietal cells (Fig. 2, 1969), and severe atrophic gastritis with dense infiltration of lymphocytes and moderate numbers of plasma and polymorphonuclear cells but no parietal cells. A barium meal and follow through (1966) showed markedly hypertrophic gastric and duodenal folds (Fig. 3); the mucosal pattern of upper loops of the jejunum was distorted. There was flocculation in the jejunum and rapid transit through the small intestine Fig. 4 (1969), and gastric and duodenal folds were prominent. Gastric analysis (Tables I and II) showed no circulating intrinsic factor antibodies in serum (1969).

\section{DISCUSSION}

Gastric function tests in our patient repeatedly showed markedly raised basal acid output and the ratios of the basal acid output (BAO) to the maximal acid output (MAO) and basal acid concentration (BAC) to maximal acid concentration (MAC) were always greater than $0 \cdot 6$. Such characteristic findings on gastric analysis have been reported only in the Zollinger-Ellison syndrome (Marks, Selzer, Louw, and Bank, 1961; Aoyagi and Summerskill, 1966; Ruppert, Greenberger, Boman, and McCullough, 1967) or excluded the gastric antrum in a postoperative condition (Scobie, McGill, Priestley, and Rovelstad, 1964). In our patient the consistently high basal acid secretion observed for over two years, the characteristic radiological findings in the stomach and duodenum, and marked hyperplasia of parietal cells on gastric biopsy should be considered adequate for the diagnosis of the Zollinger-Ellison syndrome. A negative exploration in our patient does not exclude the diagnosis of the Zollinger-Ellison syndrome as the tumour may be extremely small or aberrant pancreatic tissue may be in the duodenum (Ober- 


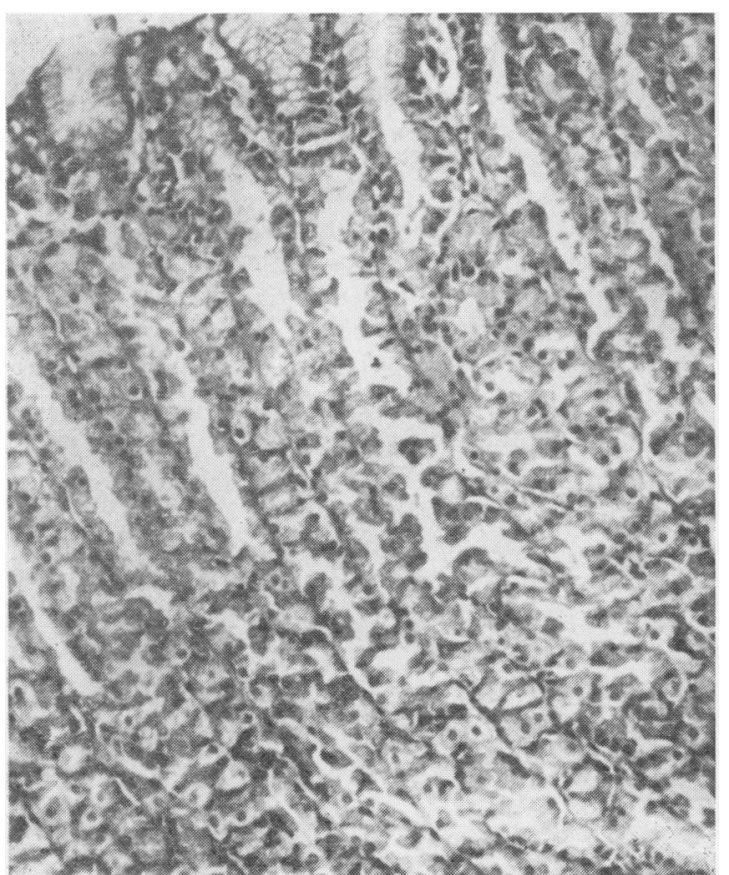

FIG. 1. Gastric biopsy showing markedly increased glandular structure in 1966.

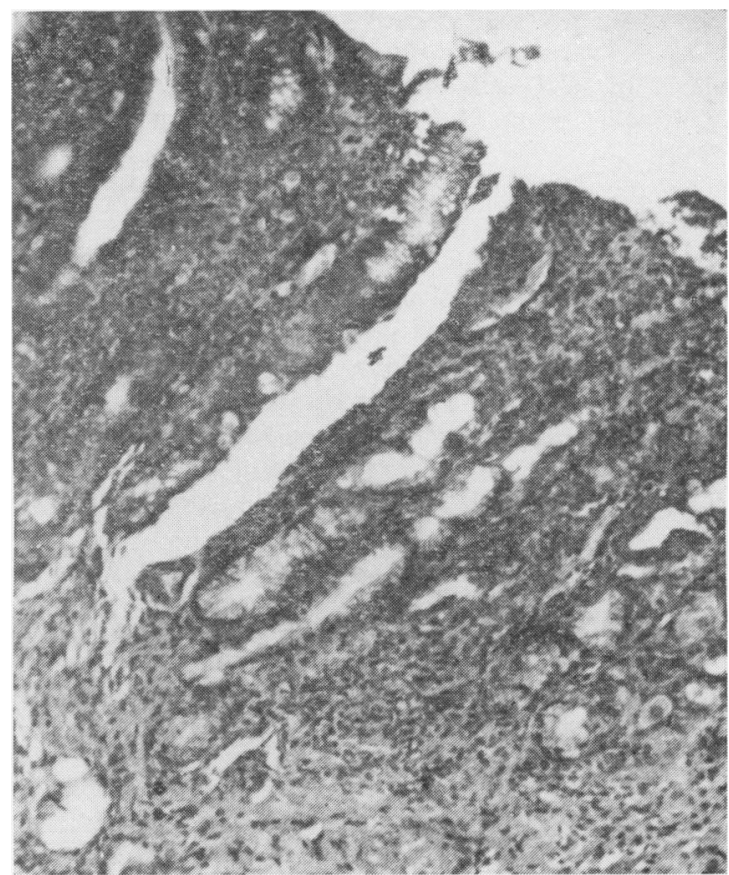

FIG. 2. Gastric biopsy showing severe atrophic gastritis with infiltration of lymphocyte and plasma cells in 1969.

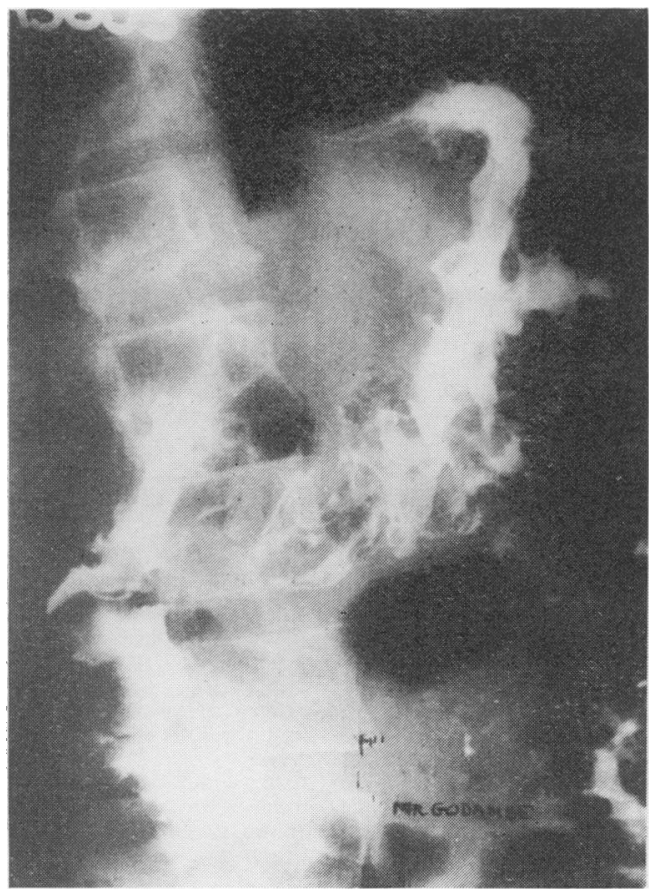

FIG. 3.

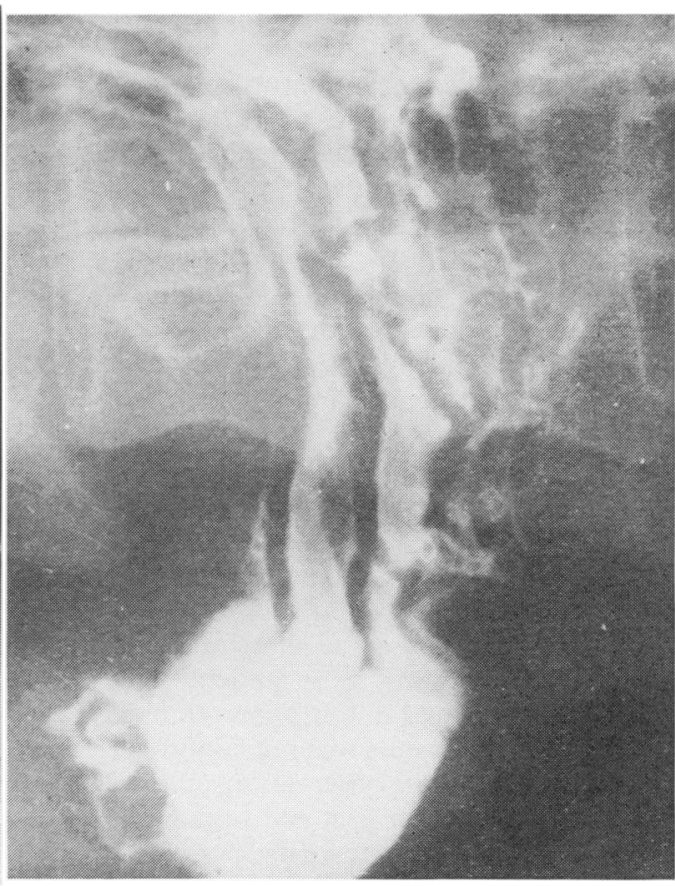

FIG. 4.
FIG. 3. Prominent gastric and duodenal folds on barium meal study in 1966.

FIG. 4. Barium meal study still shows prominent gastric folds in 1969. 
helman, Nelsen, Johnson, and Dragstedt, 1961; Shay, Chey, Koide, and Burnett, 1962) or hyperplasia of islet cells may be the only abnormality (Zollinger and McPherson, 1958; Summerskill, 1959).

In the Zollinger-Ellison syndrome with peptic ulceration (Ellison and Wilson, 1964; Zollinger and Grant, 1964) chronic diarrhoea occurs in about 30 to $40 \%$ of patients and it may precede peptic ulceration by one to six years (Zollinger and Ellison, 1955; Summerskill, 1959). About 7 to $10 \%$ of patients with the Zollinger-Ellison syndrome suffer from diarrhoea (and gastric hypersecretion) only and peptic ulceration does not occur (Ellison and Wilson, 1964). Furthermore, hypokalaemia is observed in more than $50 \%$ of patients with chronic diarrhoea and the Zollinger-Ellison syndrome (Ellison and Wilson, 1964). These observations show that chronic diarrhoea and hypokalaemia are features not only of 'pancreatic cholera' but also of the Zollinger-Ellison syndrome. The important distinguishing features of the two syndromes of non-beta islet cell tumours are high basal acid secretion with peptic ulceration in the Zollinger-Ellison syndrome whereas in 'pancreatic cholera' there is hypo- or achlorhydria, watery diarrhoea, and no peptic ulceration. In our patient high basal acid secretion without peptic ulceration for more than two years followed by spontaneous, persistent achlorhydria showed that hypersecretion and subsequent achlorhydria could occur in the same individual over the course of time. It is not unreasonable to suggest that some patients with non-beta cell pancreatic tumour, chronic diarrhoea, and achlorhydria (or low acid secretion) reported in the literature might have the same high basal acid secretion earlier in the illness as was observed in our patient.

Three cases in some respects similar to our patient are reported. Lawrie, Williamson, and Hunt (1962) observed markedly raised acid output ( $58 \mathrm{~m}$-equiv/15 min) on a test meal in a patient with the ZollingerEllison syndrome and achlorhydria was noted five months after stopping treatment with poldine methyl methosulphate (an anticholinergic agent). The authors attributed achlorhydria in their patient to the 'dramatic response to intensive medical treatment'. It may be assumed that achlorhydria had occurred spontaneously as anticholinergic drugs do not depress gastric acid secretion permanently. Maynard and Point (1958) observed diarrhoea and achlorhydria on two occasions in a patient who subsequently showed high acid output. Even though achlorhydria in these two patients was not confirmed with histamine stimulation these observations suggest that in a patient with non-beta islet cell tumour of the pancreas, if followed for some years, both high basal acid secretion and achlorhydria could be detected. Melnyk, Krippaehna, Benson, and Dunphy (1965) reported markedly diminished basal acid secretion after removal of a small lymph node from the abdomen of a patient suffering from an extensive unresectable non-beta islet cell pancieatic carcinoma. Furthermore, unexplained marked regression of primary and metastatic islet cell tumours of the Zollinger-Ellison syndrome a few years after total gastrectomy has been reported (Friesen, 1967).

Achlorhydria in our patient has obviously resulted from anatomical damage to parietal cells, as gastric biopsy in 1969 showed severe, atrophic gastritis and the absence of parietal cells. Marked infiltration with lymphocytes, plasma, and polymorphonuclear cells suggest that perhaps some inflammatory or immunological process is involved in causing atrophic gastritis. Specific antibodies were detected in rabbits after injection of C-terminal tetrapeptide amide of gastrin conjugated with gamma globulin (McGuigan, 1967). Since antibodies against Cterminal tetrapeptide react specifically with human gastrin, porcine gastrin, or cholecystokinin-pancreozymin (McGuigan, 1968), antibodies (if formed) against pentagastrin may neutralize the action of circulating gastrin. Our patient, secreting large amounts of acid for more than two years, developed achlorhydria within a few months after an injection of pentagastrin (Table I). Whether this sequence of events was accidental or resulted from the formation of specific antibodies against pentagastrin (a foreign substance) is not clear. Would it not be worthwhile to inject pentagastrin (? conjugated with gamma globulin) repeatedly in patients with the ZollingerEllison syndrome with a view to forming antibodies and thus provide an effective medical treatment for this serious disease?

\section{REFERENCES}

Aoyagi, T., and Summerskill, W. H. J. (1966). Gastric secretion with ulcerogenic islet cell tumour. Arch. intern. Med., 117, 667-672.

Brown, C. H., Neville, W. E., and Hazard, J. B. (1950). Islet-cell adenoma without hypoglycemia causing duodenal obstruction. Surgery, 27, 616-620.

- and Crile, G., Jr. (1964). Pancreatic adenoma with intractable diarrhea, hypokalemia, and hypercalcemia. J. Amer. med. Ass., 190, 30-34.

Chears, W. C., Thompson, J. B., Hutcheson, J. B., and Patterson, C. O. (1960). Pancreatic islet tumour with severe diarrhea. Amer. J. Med., 29, 529-533.

Ellison, E. H., and Wilson, S. D. (1964). The Zollinger-Ellison syndrome: reappraisal and evaluation of 260 registered cases. Ann. Surg., 160, 512-530.

Espiner, E. A., and Beaven, D. W. (1962). Non-specific islet-cell tumour of the pancreas with diarrhoea. Quart. J. Med., 31, 447471 .

Friesen, S. R. (1967). Effect of total gastrectomy on the ZollingerEllison tumor: observations on second-look procedures. Surgery, 62, 609-613.

Gregory, R. A., Tracy, H. J., French, J. M., and Sircus, W. (1960) Extraction of a gastrin-like substance from a pancreatic tumour in a case of Zollinger-Ellison syndrome. Lancet, 1, 1045-1048. 
- - Grossman, M. I., Tracy, H. J., and Bentley, P. H. (1967). Nature of the gastric secretagogue in Zollinger-Ellison tumours. Ibid, 2, 543-544.

Hallenbeck, G. A., Code, C. F., and Kennedy, J. C. (1963). Effects of gastric and primary and metastatic pancreatic islet cell tumours on gastric secretion. Gastroenterology, 44, 631-636.

Hindle, W., McBrien, D. J., and Creamer, B. (1964). Watery diarrhoea and an islet cell tumour. Gut, 5, 359-362.

Lawrie, R. S., Williamson, A. W. R., and Hunt, J. N. (1962). Zollinger-Ellison syndrome treated with Poldine methylmethosulphate. Lancet, 1, 1002-1004.

Marks, I. N., Selzer, G., Louw, J. H., and Bank, S. (1961). ZollingerEllison syndrome in a Bantu woman with isolation of a gastrinlike substance from the primary and secondary tumours. I. Case report. Gastroenterology, 41, 77-86.

Matsumoto, K. K., Peter, J. B., Schultze, R. G., Hakim, A. A., and Franck, P. T. (1966). Watery diarrhea and hypokalemia associated with pancreatic islet cell adenoma. Ibid, 50, 231-242.

Maynard, E. P., and Point, W. W. (1958). Steatorrhea associated with ulcerogenic tumour of pancreas. Amer. J. Med., 25, 456-459.

McGuigan, J. E. (1967). Antibodies to the carboyl-terminal tetrapeptide of gastrin. Gastroenterology, 53, 697-705.

- (1968). Antibodies to the C-terminal tetrapeptide amide of gastrin. Assessment of antibody binding to cholecystokininpancreozymin. Ibid, 54, 1012-1017.

Melnyk, C. S., Krippaehne, W. W., Benson, J. A., Jr, and Dunphy, J. E. (1965). Spontaneous remission of Zollinger-Ellison syndrome. Arch. Intern. Med. (Chicago), 115, 42-47.

Murray, J. S., Paton, R. R., and Pope, C E. (1961). Pancreatic tumor associated with flushing and diarrhea. New. Engl. J. Med., 264, 436-439.

Oberhelman, H. A., Nelsen, T. S., Johnson, A. N., and Dragstedt, L. R. (1961). Ulcerogenic tumours of the duodenum. Ann. Surg., 153, 214-227.

Ruppert, R. D., Greenberger, N. J., Beman, F. M., and McCullough, F. M. (1967). Gastric secretion in ulcerogenic tumours of the pancreas. Ann. Intern. Med.. 67, 808-810.

Scobie, B. A., McGill, D. B., Priestley, J. T., and Rovelstad, R. A. (1964). Excluded gastric antrum simulating the ZollingerEllison syndrome. Gastroenterology, 47, 184-187.

Shay, H., Chey, W. Y., Koide, S. M., and Burnett, W. E. (1962). Mechanism of the disordered physiology involved in the Zollinger-Ellison syndrome. Report of a case. Amer. J. dig. Dis., 7, 401-419.

Summerskill, W. H. J. (1959). Malabsorption and jejunal ulceration due to gastric hypersecretion with pancreatic islet-cell hyperplasia. Lancet, 1, 120-123.

Telling, M., and Smiddy, F. G. (1961). Islet tumours of the pancreas with intractable diarrhoea. Gut, 2, 12-17.

Verner, J. V., and Morrison, A. B. (1958). Islet cell tumor and a syndrome of refractory watery diarrhea and hypokalemia. Amer. J. Med., 25, 374-380.

Zollinger, R. M., and Ellison, E. H. (1955). Primary peptic ulceration of the jejunum associated with islet cell tumours of the pancreas. Ann. Surg., 142, 709-723.

- and Grant, G. N. (1964). Ulcerogenic tumour of the pancreas. J. Amer. med. Ass., 190, 181-184.

-, and McPherson, R. C. (1958). Ulcerogenic tumors of the pancreas. Amer. J. Surg., 95, 359-365. 